\title{
The Solution of Discrepancy of Late Deceleration and the Prevention of Cerebral Palsy by the Hypoxia Index
}

\author{
Kazuo Maeda* \\ Honorary professor, Obstetrics \& Gynecology, Tottori University Medical School, Japan
}

Submission: April 23, 2018; Published: May 08, 2018

*Corresponding author: Kazuo Maeda, Honorary professor, Obstetrics \& Gynecology, Tottori University Medical School, Japan,

Email: maedak@mocha.ocn.ne.jp

\section{Solution of Fetal Heart Rate Discrepancy}

Although the late deceleration (LD) of fetal heart rate (FHR) was ominous outcome sign in fetal monitoring [1], there was discreparency, namly, the neonatal outcome of 3 connective LDs was vigorous \& normal, while the neonate afterrepeated LDs in 50 minutes was severe asphyxia, whose Apgar score was 3, and follwed by brain hemorrage \& death 3 months later. However the difference was caused by the repetition of deceleration (transient fetal bradycardia) but not due to abnormal form of late deceleration.

Thus, the author intended to evaluate the sum of deceleration durations (min) divided by the lowest FHR (bpm, the hypoxic intensity) multiplied by 100, that was Maeda's hypoxia index (HI), which was the same as the hypoxic area (dip area), and it was the sum of hypoxic effects of repeated decelerations, that was as weak as 6 in 3 decelrations, but as strong as 26 after 50 minutes reprtitions. The LD discrepancy was solved by hypoxia index.

Preventin of Cerebral Palsy Caused by Intrapartum Hypoxic Fetal Damage

As fetal brain reacts fetal movements then heart rate inreases, fal brain reacts by fetal movenent group (movement bursts) forming acceieration (transient tachycardia), the acceleration disappears in early statge of hypoxia due to the suppression of fetal bain, while fetal brain reacts minor fetal movements,andforms FHR variability, which disappears at severe hypoxia after the loss of acceleration, the loss of variability is the most severe fetal hypoxia, that was the same as anencephalic fetus [2]. The hypoxia index of all 6 cases, whose variability was lost, developed severe fetal brain damage followed by cerebral palsy was 25 or more, whreas the hypxia index of 16 cases of normal variability and follwed by no cerebeal palsy hypoxia index of 6 cases of nrmal variabilty, no intrapartum brain damage, and followed by no cerebral palsy was 24 or less (Table 1).
Table 1: $\mathrm{Chi}^{2}$ test of hypoxia index of 25 or more and 24 or less in cases of cerebral palsy and normal outcome.

Intrapartum Brain Damage Followed by Cerebral Palsy

\begin{tabular}{|l|c|c|c|c|}
\hline \multirow{3}{*}{ Hypoxia index } & & Yes & No & \multirow{2}{*}{$\mathrm{p}=0.000008$} \\
\cline { 2 - 4 } & 25 or more & 6 & 0 & \\
\cline { 2 - 4 } & 24 or less & 0 & 16 & \\
\hline
\end{tabular}

Thus, cerebral palsy caused by intrapartum hypoxic daage will be prevented, if hypoxia index is 24 or less.

\section{Computerized Fetal Monitoring}

FHR score, hypoxia index and FHR curve frequency spectrum will be included.

(1) FHR score calculated every 5 minutes.

Apgar score and UApH are expected by regression equations. Direct report to doctor from computer (Table 2).

Table 2:Expected Apgar score, neonatal aspyxia and umbilical arterial $\mathrm{pH}$.

\begin{tabular}{|c|c|c|c|}
\hline FHR Score & $\begin{array}{c}\text { Expected } \\
\text { Apgar Score }\end{array}$ & Asphyxia & UApH \\
\hline$<10$ & $>7$ & No & $>7.3$ \\
\hline 10 & 6 & Mild & no acidosis \\
\hline 15 & 4 & Moderate & Acidosis \\
\hline 20 & 3 & Severe & Acidosis \\
\hline
\end{tabular}

i. Hypoxia index

a) Direct report from computer to doctor when hypoxia index is positive.

b) Hypoxia index is reported every 5 minutes after positive hypoxia index.

c) Hypoxia index must be 24 or less at delivery.

d) No diagnosis of deceleration pattern (Observe FHR curve ) 
ii. Frequency spectrum data

a) Pathologic sinusoidal FHR and its La/Ta and PPSD values are reported doctor.

iii. Fetal hiccupping must be diagnosed in continuous spikes but no movement burst

(Observe actocardiogram, as no fetal movement is diagnosed by cmputer)

This work is licensed under Creative

Commons Attribution 4.0 License

DOI: 10.19080/CTBEB.2018.14.555883
References

1. Hon EH (1968) An Atlas of Fetal Heart Rate Pattern. Harty Press, New Haven, USA.

2. Maeda K (2014) Modalities of fetal evaluation to detect fetal compromise prior to the development of significant neurological damage. JOGR 40: 20892094

Your next submission with Juniper Publishers will reach you the below assets

- Quality Editorial service

- Swift Peer Review

- Reprints availability

- E-prints Service

- Manuscript Podcast for convenient understanding

- Global attainment for your research

- Manuscript accessibility in different formats ( Pdf, E-pub, Full Text, Audio)

- Unceasing customer service

Track the below URL for one-step submission https://juniperpublishers.com/online-submission.php 